\title{
15. COCCOLITH AGE DETERMINATIONS LEG 1, DEEP SEA DRILLING PROJECT
}

\author{
David Bukry, ${ }^{1}$ U. S. Geological Survey, La Jolla, California \\ and \\ M. N. Bramlette, Scripps Institution of Oceanography, La Jolla, California
}

This report combines the results of study of over 400 coccolith samples taken for shipboard and onshore investigation during Leg 1 of the Deep Sea Drilling Project, August-September 1968. Both electron-microscope and light-microscope techniques have been used to identify stratigraphically important coccoliths. Following a brief summary of the coccolith stratigraphy for each drilling site, the age-diagnostic species in selected samples are listed, and in Figures 1 through 3 the geologic ages determined from the assemblages at each site are summarized graphically.

For purposes of comparison, this volume contains another report on coccolith ages in a different set of samples from these same cores, prepared by W. W. Hay of the Institute of Marine Sciences, University of Miami. The samples in that report were taken from the upper part of each core section, whereas ours came from the middle of each section. Except for Hole 1, our material also includes many additional smear-slide samples prepared from other places in the cores during the shipboard operations.

The sample numbers, which identify, the relative position of samples in the holes, consist of a series of numbered and lettered entries separated by hyphens in the following sequence: (cruise-leg number) - (drill-hole designation, consisting of site number plus a letter, if more than one hole) - (core-run number) - (coresection number). This series is followed by the interval below the top of each core section in centimeters. For example, 1-6A-1-1, 75-76 centimeters, means the sample came from Leg 1, Hole 6A (at Site 6), the first barrel of core recovered, the top section of that core, and from 75-76 centimeters below the top of the section. Most core runs were 9.1 meters long, but commonly the core liners were not full. In this report, recoveries are arbitrarily placed at the top of the core runs, and an approximate depth in meters below the sea floor follows each sample number.

\footnotetext{
${ }^{1}$ Publication authorized by the Director, U.S. Geological Survey.
}

HOLE 1

(lat $25^{\circ} 51.5^{\prime} \mathrm{N}$., long $92^{\circ} 11.0^{\prime} \mathrm{W}$., depth 2827 meters)

\section{Summary of Coccolith Age Determinations}

A thick sequence of Pleistocene sediment at the Hole 1 locality near the continental slope of the Gulf Coast contains a coccolith flora that has been greatly diluted by Mississippi River detritus that contains reworked late Cretaceous coccoliths. The indigenous Pleistocene coccoliths such as Ceratolithus cristatus Kamptner and Gephyrocapsa oceanica Kamptner occur in abundance

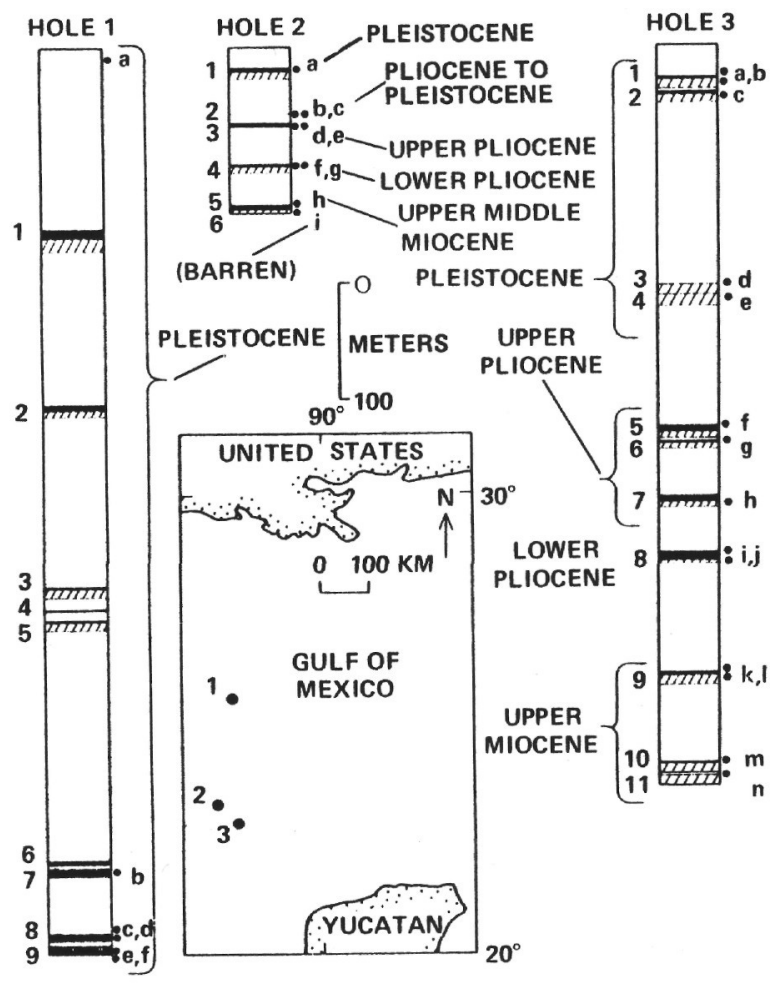

Figure 1. Series represented in cores from the Gulf of Mexico based on coccolith assemblages. Core number to left of columns, sample to right. 
only near the top of the sediment section (sampled by piston core). Deeper cores are characterized by a sparse occurrence of all coccoliths and by a large proportion of reworked Cretaceous species such as Eiffellithus turriseiffeli (Deflandre), Cribrosphaera ehrenbergi Arkhangelsky, and Micula decussata Vekshina.

Age-diagnostic Coccoliths in Selected Samples, Hole 1

\section{Pleistocene}

Sample a (1-1P-1-3, $70 \mathrm{~cm}$, depth $4 \mathrm{~m})$ : Ceratolithus cristatus Kamptner; Helicopontosphaera kamptneri Hay and Mohler; Cyclococcolithus leptoporus (Murray and Blackman); ?Gephyrocapsa sp. Reworked late Cretaceous taxa: Eiffellithus turriseiffeli (Deflandre); Watznaueria barnesae (Black); Zygodiscus diplogrammus (Deflandre).

Sample b (1-1-7-4, 3-4 cm, depth $699 \mathrm{~m})$ : Reworked late Cretaceous taxa: Eiffellithus turriseiffeli (Deflandre); Micula decussata Vekshina; Watznaueria barnesae (Black); Zygodiscus sp.

Sample c $\quad(1-1-8-2,77-78 \mathrm{~cm}$, depth $753 \mathrm{~m})$ : Reworked late Cretaceous taxa: Eiffellithus turriseiffeli (Deflandre); Prediscosphaera cretacea (Arkhangelsky); Watznaueria barnesae (Black); Zygodiscus sp.

Sample d (1-1-8-7, 76-77 cm, depth $761 \mathrm{~m})$ : Gephyrocapsa oceanica Kamptner. Reworked late Cretaceous taxa: Chiastozygus disgregatus (Stover); Eiffellithus turriseiffeli (Deflandre); Watznaueria barnesae (Black).

Sample e (1-1-9-3, 73-74 cm, depth $764 \mathrm{~m})$ :

Reworked late Cretaceous taxa: Arkhangelskiella concava Gartner; A. parca Stradner, Cribrosphaera ehrenbergi Arkhangelsky; Eiffellithus octoradiatus (Gorka); E. turriseiffeli (Deflandre); Markalius sp.; Microrhabdulus decoratus Deflandre; Micula decussata Vekshina; Prediscosphaera cretacea (Arkhangelsky); Watznaueria barnesae (Black).

Sample f $\quad(1-1-9-4,74-75 \mathrm{~cm}$, depth $765 \mathrm{~m})$ :

Gephyrocapsa oceanica Kamptner; Helicopontosphaera kamptneri Hay and Mohler. Reworked late Cretaceous taxa: Arkhangelskiella parca Stradner; Cribrosphaera ehrenbergi Arkhangelsky; Micula decussata Vekshina.

HOLE 2

(lat $23^{\circ} 27.3^{\prime} \mathrm{N}$., long $92^{\circ} 35.2^{\prime} \mathrm{W}$., depth 3572 meters)

\section{Summary of Coccolith Age Determinations}

Coring operations on Challenger Knoll recovered sediment samples ranging in age from late Middle Miocene to Pleistocene. The first core contains a typical Pleistocene assemblage of coccoliths. Core 2 contains a transitional assemblage. Although it could be late Pliocene in age, it is probably early Pleistocene. This assignment is indicated by the rare occurrence of discoasters, by the occurrence of a variety of Ceratolithus rugosus Bukry and Bramlette with a concave arch that indicates the last occurrence of this species, and by the presence of a few specimens of the large form Cyclococcolithus leptoporus (Murray and Blackman), var. A of McIntyre, Bé, and Preikstas. Late Pliocene coccolith assemblages characterized by abundant three- and six-rayed specimens of Discoaster brouweri Tan are present in Core 3. In Core 4, a discoaster assemblage, the common occurrence of Reticulofenestra pseudoumbilica (Gartner) and Sphenolithus sp. aff. S. abies (Deflandre), along with C. rugosus indicate an early Pliocene age.

Probably because of salt-dome piercement the oldest sample recovered in this hole consists of a few chips of late Middle Miocene grey lutite at the top of the core barrel that contained oil and salt-dome cap rock. Identification of such species as Discoaster bollii Martini and Bramlette (common) and Catinaster sp. aff. C. Coalitus Martini and Bramlette (several specimens) indicates a late Middle Miocene age for the sediment above the cap rock. The coccolith assemblage is probably correlative to that of the upper part of Bolli's Globorotalia menardii Range Zone of foraminifera in Trinidad (see Bramlette and Wilcoxon, 1967). Black siltstone within the cap rock contains no calcareous microfossils.

Age-diagnostic Coccoliths in Selected Samples, Hole 2

\section{Pleistocene}

Sample a $\quad$ (1-2-1, core catcher, depth $23 \mathrm{~m})$ :

Ceratolithus cristatus Kamptner; Gephyrocapsa oceanica Kamptner; Rhabdosphaera stylifera Lohmann.

\section{Early Pleistocene}

Sample b (1-2-2-1, 76-77 cm, depth $58 \mathrm{~m})$ : Ceratolithus cristatus Kamptner; C. rugosus Bukry and Bramlette; Cyclococcolithus leptoporus (Murray and Blackman), var. A of McIntyre, Bé, and Preikstas; Discoaster brouweri Tan; $D$. pentaradiatus Tan; Rhabdosphaera clavigera Murray and Blackman; $R$. stylifera Lohmann.

Sample c $\quad(1-2-2$, core catcher, depth $59 \mathrm{~m})$ : Ceratolithus rugosus Bukry and Bramlette; Discoaster brouweri Tan; Helicopontosphaera kamptneri Hay and Mohler; Rhabdosphaera stylifera Lohmann.

\section{Late Pliocene}

Sample d (1-2-3-1, $1 \mathrm{~cm}$, depth $67 \mathrm{~m})$ : Ceratolithus rugosus Bukry and Bramlette; Cyclococcolithus leptoporus (Murray and Blackman), var. A of McIntyre, Bé, and Preikstas; Discoaster brouweri Tan; Helicopontosphaera kamptneri Hay and Mohler; Rhabdosphaera clavigera Murray and Blackman. 
Sample e (1-2-3, core catcher, depth $71 \mathrm{~m})$ :

Ceratolithus rugosus Bukry and Bramlette; Cyclococcolithus leptoporus (Murray and Blackman), var. A of McIntyre, Bé, and Preikstas; Discoaster brouweri Tan; D. pentaradiatus Tan; D. surculus Martini and Bramlette.

\section{Early Pliocene}

Sample f (1-2-4-1, 41-42 cm, depth $102 \mathrm{~m})$ : Ceratolithus rugosus Bukry and Bramlette; Discoaster brouweri Tan; D. challengeri Bramlette and Riedel; D. pentaradiatus Tan;D. surculus Martini and Bramlette; Reticulofenestra pseudoumbilica (Gartner); Sphenolithus sp. aff. S. abies (Deflandre).

Sample g (1-2-4-2, $100 \mathrm{~cm}$, depth $104 \mathrm{~m})$ : Ceratolithus rugosus Bukry and Bramlette; Cyclococcolithus leptoporus (Murray and Blackman); Discoaster brouweri Tan; D. challengeri Bramlette and Riedel; D. surculus Martini and Bramlette; D. sp.; Reticulofenestra pseudoumbilica (Gartner).

\section{Late Middle Miocene}

Sample h (1-2-5, top of recovery, depth $136 \mathrm{~m})$ : Catinaster sp. aff. C. coalitus Martini and Bramlette; Coccolithus pelagicus (Wallich); Discoaster bollii Martini and Bramlette; $D$. brouweri Tan; D. variabilis Martini and Bramlette; D. sp.; Reticulofenestra pseudoumbilica (Gartner).

Sample i (1-2-6, core catcher, depth $141 \mathrm{~m})$ :

Barren.

HOLE 3

(lat $23^{\circ} 01.0^{\prime} \mathrm{N}$., long $92^{\circ} 01.4^{\prime} \mathrm{W}$., depth 3746 meters)

\section{Summary of Coccolith Age Determinations}

The first four cores recovered from this hole contain coccolith assemblages of Pleistocene age. The upper two cores contain an admixture of reworked late Cretaceous coccoliths, as do most of the Pleistocene cores from Hole 1. Cores 5, 6, and 7 are characterized by late Pliocene coccolith assemblages containing Ceratolithus rugosus Bukry and Bramlette, Discoaster brouweri Tan, D. pentaradiatus Tan, and abundant small coccoliths probably related to Coccolithus doronicoides Black and Barnes. Core 8 , the level which was selected on the basis of shipboard predictions of the position of the Miocene-Pliocene boundary by $\mathrm{W}$. Berggren and D. Bukry (based on sedimentation rates calculated from the upper 7 cores), contains a coccolith assemblage indicating the earliest Pliocene. Of particular interest in it is the overlap of $C$. rugosus with Ceratolithus tricorniculatus Gartner, emended, which occurs only in sediment of latest Miocene or early Pliocene age (Bukry and Bramlette, 1968). This core is considered to be earliest Pliocene because of the numerical dominance of $C$. tricorniculatus among the ceratoliths and because of the presence of small numbers of an undescribed discoaster species that is abundant in late Miocene assemblages.

The discoaster assemblage in Cores 9, 10, and 11 are dominated by such species as Discoaster calcaris Gartner, D. challengeri Bramlette and Riedel, D. variabilis Martini and Bramlette, and $D$. sp. (undescribed), which indicate a late Miocene age. Calcareous detritus and reworked coccoliths of Middle Miocene, Eocene, and late Cretaceous age are present in most samples from these lower three cores.

Age-diagnostic Coccoliths in Selected Samples, Hole 3

\section{Pleistocene}

Sample a $\quad(1-3-1-1,112 \mathrm{~cm}$, depth $26 \mathrm{~m})$ :

Ceratolithus cristatus Kamptner; Gephyrocapsa oceanica Kamptner; Helicopontosphaera kamptneri Hay and Mohler; Thoracosphaera sp.

Sample b (1-3-1, core catcher, depth $28 \mathrm{~m})$ Gephyrocapsa oceanica Kamptner; Helicopontosphaera kamptneri Hay and Mohler. Reworked late Cretaceous taxa: Arkhangelskiella parca Stradner; Eiffellithus turriseiffeli (Deflandre); E. octoradiatus (Gorka); Watznaueria barnesae (Black).

Sample c $\quad(1-3-2-3,75 \mathrm{~cm}$, depth $39 \mathrm{~m})$ :

Cyclococcolithus leptoporus (Murray and Blackman); Gephyrocapsa oceanica Kamptner; Rhabdosphaera clavigera Murray and Blackman. Reworked late Cretaceous taxa: Arkhangelskiella parca Stradner;Micula decussata Vekshina; Watznaueria barnesae (Black).

Sample d (1-3-3, core catcher, depth $202 \mathrm{~m})$ :

Cyclococcolithus leptoporus (Murray and Blackman); Gephyrocapsa oceanica Kamptner.

Sample e (1-3-4-1, $90 \mathrm{~cm}$, depth $210 \mathrm{~m})$ : Ceratolithus cristatus Kamptner; Gephyrocapsa oceanica Kamptner; Helicopontosphaera kamptneri Hay and Mohler; Thoracosphaera sp.

\section{Late Pliocene}

Sample f (1-3-5, top of recovery, depth $320 \mathrm{~m})$ : Ceratolithus rugosus Bukry and Bramlette; Discoaster brouweri Tan; D. pentaradiatus Tan; Helicopontosphaera kamptneri Hay and Mohler; Rhabdosphaera clavigera Murray and Blackman.

Sample g (1-3-6, top of recovery, depth $330 \mathrm{~m})$ : Ceratolithus rugosus Bukry and Bramlette; Discoaster brouweri Tan; $D$. pentaradiatus Tan.

Sample h (1-3-7, core catcher, depth $387 \mathrm{~m})$ : Cyclococcolithus leptoporus (Murray and Blackman); 
Discoaster brouweri Tan; D. pentaradiatus Tan; $D$. surculus Martini and Bramlette.

\section{Early Pliocene}

Sample i (1-3-8, top of recovery, depth $430 \mathrm{~m})$ : Ceratolithus rugosus Bukry and Bramlette; Discoaster brouweri Tan; $D$. pentaradiatus Tan; $D$. surculus Martini and Bramlette; Reticulofenestra pseudoumbilica (Gartner); Sphenolithus sp. aff. S. abies Deflandre.

Sample j (1-3-8, core catcher, depth $438 \mathrm{~m})$ : Ceratolithus rugosus Bukry and Bramlette; C. tricorniculatus Gartner, emended; Discoaster brouweri Tan; D. surculus Martini and Bramlette;D. sp.;Reticulofenestra pseudoumbilica (Gartner); Sphenolithus sp. aff. S. abies Deflandre.

\section{Late Miocene}

Sample k (1-3-9, top of recovery, depth $534 \mathrm{~m})$ :

Discoaster brouweri Tan; $D$. challengeri Bramlette and Riedel; D. variabilis Martini and Bramlette; $D$. sp.; Helicopontosphaera kamptneri Hay and Mohler; Sphenolithus abies Deflandre.

Sample 1 (1-3-9, core catcher, depth $543 \mathrm{~m})$ : Catinaster sp.; Discoaster brouweri Tan; D. calcaris Gartner;D. surculus Martini and Bramlette; $D$. variabilis Martini and Bramlette; $D$. sp.

Sample m (1-3-10-1, $150 \mathrm{~cm}$, depth $611 \mathrm{~m})$ :

Discoaster brouweri Tan; D. calcaris Gartner; $D$. challengeri Bramlette and Riedel; $D$. variabilis Martini and Bramlette; Reticulofenestra pseudoumbilica (Gartner). Reworked specimens: Discoaster barbadiensis Tan; D. bollii Martini and Bramlette;Zygodiscus diplogrammus (Deflandre).

Sample n (1-3-11-1, composite, depth $620 \mathrm{~m}$ to $621 \mathrm{~m}$ ):

Cyclococcolithus leptoporus (Murray and Blackman); Discoaster brouweri Tan; D. calcaris Gartner; D. challengeri Bramlette and Riedel; D. calcaris Gartner and Bramlette; Reticulofenestra pseudoumbilica (Gartner). Reworked specimens: Catinaster coalitus Martini and Bramlette; Watznaueria barnesae (Black); Zygodiscus diplogrammus (Deflandre).

\section{HOLES 4 AND 4A}

(lat $24^{\circ} 28.7^{\prime} \mathrm{N}$., long $73^{\circ} 47.5^{\prime} \mathrm{W}$., depth 5319 meters)

\section{Summary of Coccolith Age Determinations}

Core 1 extends from the surface to a depth of 9.1 meters. The upper 6 meters contain a mixture of coccoliths of Cretaceous, Eocene, Oligocene, Miocene, and Pliocene age. Although the Miocene specimens are numerically dominant, the youngest coccoliths present are Pliocene in age. Samples from the bottom of this core

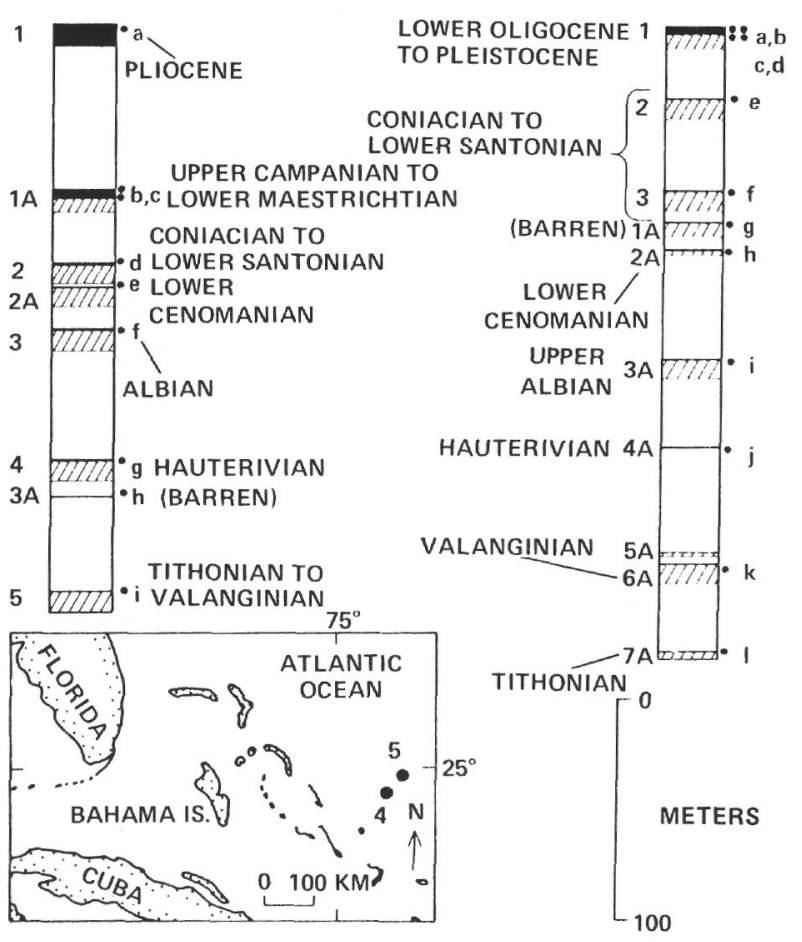

Figure 2. Series and stages represented in cores from the Blake-Bahama Basin based on coccolith assemblages. Core number to left of columns, sample to right.

are essentially barren. In superposable sequence, the next older core recovered is $1 \mathrm{~A}$, which contains Cretaceous coccolith assemblages of latest Campanian to early Maestrichtian age. As there is no evident change in species composition in the assemblages through this core, and since criteria for distinguishing late Campanian sediment from that of early Maestrichtian are not now available, further refinement of this age is impossible. The sparse assemblage of coccoliths in Core 2, including Rucinolithus hayi Stover and Marthasterites furcatus Deflandre, is Coniacian to early Santonian in age. Core $2 \mathrm{~A}$ is assigned an early Cenomanian age based on the presence of Prediscosphaera cretacea (Arkhangelsky),Zygodiscus ponticulus (Deflandre), and $Z$. xenotus (Stover), in the absence of Prediscosphaera columnatus Stover and Cretarhabdus decorus (Deflandre). The coccolith assemblage in Core 3 correlates well to Albian coccolith assemblages described from European samples (Bukry, 1969; Reinhardt, 1966; Stradner, 1963; Stradner, Adamiker, and Maresch, 1968; Stover, 1966). Sediment in Core 4 has a characteristic early Cretaceous assemblage containing specimens of Nannoconus steinmanni Kamptner and vast numbers of Braarudosphaera discula Bramlette and Riedel of Stradner. Also present is the coccolith Micrantholithus obtusus Stradner, 
which is diagnostic of Hauterivian age (Percival, S., personal communication, 1968; Reinhardt, 1966; Stradner, 1963). The final core containing coccoliths, Core 5 , was taken at 250 meters below the sea floor. The coccolith assemblage is composed of fairly long-ranging species; and, a Tithonian to Valanginian age was assigned mainly because of the paucity of $B$. discula specimens, which usually are abundant in the few Barremian and Hauterivian sediments available for comparison.

Age-diagnostic Coccoliths from Selected Samples, Holes 4 and 4A

\section{Pliocene}

Sample a (1-4-1, top of recovery, depth $0 \mathrm{~m})$ : Ceratolithus rugosus Bukry and Bramlette, Cyclococcolithus leptoporus (Murray and Blackman); Discoaster brouweri Tan; $D$. pentaradiatus Tan; $D$. surculus Martini and Bramlette;Reticulofenestra pseudoumbilica (Gartner). Reworked Miocene taxa: Cyclococcolithus neogammation Bramlette and Wilcoxon; Discoaster aulakos Gartner; Helicopontosphaera ampliaperta (Bramlette and Wilcoxon); Sphenolithus heteromorphus Bramlette and Wilcoxon. Reworked Cretaceous taxa: Cretarhabdus crenulatus Bramlette and Martini; Nannoconus steinmanni Kamptner; Watznaueria barnesae (Black).

\section{Late Cretaceous}

(Late Campanian to Early Maestrichtian)

Sample b (1-4A-1, top of recovery, depth $73 \mathrm{~m}$ ): Arkhangelskiella cymbiformis Vekshina; $A$. parca Stradner; Cribrosphaera sp. cf. C. pelta (Gartner); Marthasterites inconspicuus Deflandre; Prediscosphaera spinosa (Bramlette and Martini); Tetralithus aculeus (Stradner); T. nitidus trifidus Stradner; T. pyramidus Gardet.

Sample c (1-4A-1, core catcher, depth $77 \mathrm{~m})$ : Arkhangelskiella cymbiformis Vekshina; $A$. parca Stradner; . specillata Vekshina; Biantholithus sparsus Bramlette and Martini; Tetralithus aculeus (Stradner); $T$. nitidus trifidus (Stradner); T. pyramidus Gardet.

\section{Late Cretaceous (Coniacian to Early Santonian)}

Sample d (1-4-2-1, $4 \mathrm{~cm}$, depth $104 \mathrm{~m})$ : Cribosphaera ehrenbergi Arkhangelsky, Eiffellithus eximius (Stover); Marthasterites furcatus (Deflandre); Microrhabdulus decoratus Deflandre; Rucinolithus hayi Stover; Zygodiscus exiguus (Stover); Watznaueria actinosa (Stover).

\section{Late Cretaceous (Early Cenomanian)}

Sample e (1-4A-2A, core catcher, depth $116 \mathrm{~m}$ ): Apertapetra gronosa (Stover); Eiffellithus turriseiffeli (Deflandre); Lithastrinus floralis Stradner; Parhabdolithus angustus (Stradner); Prediscosphaera cretacea
(Arkhangelsky); Zygodiscus ponticulus (Deflandre); Z. xenotus Stover.

$$
\text { Early Cretaceous (Albian) }
$$

Sample f $\quad(1-4-3-1,0-32 \mathrm{~cm}$, depth $134 \mathrm{~m})$ : Apertapetra gronosa (Stover); Arkhangelskiella erratica Stover; A. striata Stradner; Corollithion signum (Stradner); Cretarhabdus decorus (Deflandre); Eiffellithus turriseiffeli (Deflandre); Parhabdolithus angustus (Stradner); $P$. granulatus Stover; $P$. embergi Noël; Zygodiscus erectus (Deflandre); Z. ponticulus (Deflandre); Watznaueria actinosa (Stover).

\section{Early Cretaceous (Hauterivian)}

Sample g (1-4-4-1, 0-100 cm, depth $191 \mathrm{~m})$ : Braarudosphaera discula Bramlette and Riedel of Stradner; Cruciplacolithus sp.; Discolithus asper Stradner; Lithraphidites carniolensis Deflandre; Micrantholithus obtusus Stradner; Parhabdolithus embergi Noël; Nannoconus steinmanni Kamptner.

Sample h $\quad(1-4 \mathrm{~A}-3$, depth $207 \mathrm{~m})$ :

Barren.

$$
\begin{gathered}
\text { Late Jurassic (Tithonian) to } \\
\text { Early Cretaceous (Valanginian) }
\end{gathered}
$$

Sample i $\quad(1-4-5$, core catcher, depth $250 \mathrm{~m})$ :

Cruciplacolithus sp.; Discolithus asper Stradner; Lithraphidites carniolensis Deflandre; Parhabdolithus embergi Noël; Watznaueria barnesae (Black).

\section{HOLES 5 AND 5A}

(lat $24^{\circ} 43.6^{\prime} \mathrm{N}$., long $73^{\circ} 38.5^{\prime} \mathrm{W}$., depth 5361 meters)

\section{Summary of Coccolith Age Determinations}

The upper 4 meters of Core 1 contain a chaotic succession of coccolith assemblages. This recovery presumably took place during oscillatory movement of the long drill pipe resulting in irregular sampling of various layers before enough penetration of firm strata was achieved to continue in a fixed hole. As a mixed sequence was also recovered in the first core at Hole 4, it would be desirable to take supplementary piston cores of the uppermost strata. In particular, the lower part of Core 1 of Hole 5 contains a mixed layer including Pliocene coccoliths beneath homogeneous early Miocene sediment. The recovery was as follows:

1-5-1-1, 31-32 cm:

Dark clay and silt, sparse Pleistocene coccoliths, with rare reworked Tertiary coccoliths.

$1-5-1-1,100 \mathrm{~cm}$ :

Same.

$1-5-1-2,70 \mathrm{~cm}:$

Foraminiferal and coccolith ooze containing a mixture of Miocene, late Miocene, and Pliocene coccoliths. 
$1-5-1-2,140 \mathrm{~cm}:$

Foraminiferal and coccolith ooze with homogeneous early Miocene assemblage.

1-5-1-3, 3-4 cm:

Same.

$1-5-1-3,15-18 \mathrm{~cm}$ :

Same.

1-5-1-3, $21 \mathrm{~cm}$ :

Same.

1-5-1-3, 52-54 cm:

Sedimentary breccia with a mixture of coccoliths of all ages from Cretaceous to Pliocene.

1-5-1-3, $74 \mathrm{~cm}$ :

Same.

1-5-1-3, $93 \mathrm{~cm}$ :

Foraminiferal and coccolith ooze with homogeneous early Oligocene coccolith assemblage.

Cores 2 and 3 contain sparse late Cretaceous coccolith assemblages, including Marthasterites furcatus Deflandre and Micula decussata Vekshina, which aided in assigning a probable Coniacian to early Santonian age to these recoveries. The distribution and preservation of coccoliths in these two cores is unusual. The dominant coccolith species in most Cretaceous samples Watznaueria barnesae (Black) is missing, and only the coccolith rims of ?Watznaueria actinosa (Stover) are present. The central structure of these coccoliths was removed by solution, and this solution also may have completely removed other taxa from these assemblages. Core $2 \mathrm{~A}$ recovered sediment that contains few coccoliths. The presence of Prediscosphaera cretacea (Arkhangelsky), Zygodiscus ponticulus (Deflandre), and $Z$. xenotus (Stover) indicates a probable early Cenomanian age for this recovery. Examination of samples from Core $3 \mathrm{~A}$ using electron microscopy shows the rich coccolith assemblage to be correlative to the Albian of Europe (Stradner and Adamiker, 1966; and Stradner, Adamiker, and Maresch, 1968). Characteristic species include: abundant Apertapetra gronosa (Stover); common Prediscosphaera columnatus (Stover); common Cretarhabdus decorus (Deflandre); few Corollithion signum Stradner; few $C$. delftensis (Stradner, Adamiker, and Maresch). A characteristic coccolith assemblage of early Cretaceous (Hauterivian) age is present in Core 4A including abundant Braarudosphaera discula Bramlette and Riedel of Stradner, common Nannoconus globulus Brönnimann, and few Micrantholithus obtusus Stradner. The coccoliths of $B$. discula and $M$. obtusus commonly disaggregate to produce a myriad of approximately triangular calcite fragments in the fine fraction of marine sediment of this age. Cores $5 \mathrm{~A}$ and $6 \mathrm{~A}$ are dated as Valanginian on the basis of the presence of
Nannoconus bermudezi Brönnimann, N. steinmanni Kamptner, $N$. globulus Brönnimann, Discolithus asper Stradner, and because of the absence of coccoliths with Jurassic affinities. In Core 7A, electron microscopy has confirmed the presence of abundant Diazomatolithus lehmani Noël, common Watznaueria britannica (Stradner), few Nannoconus dolomiticus Cita and Pasquaré, and rare Stephanolithion bigoti Noël. This assemblage indicates a late Jurassic, Tithonian age for the core. Added indication of the late Jurassic aspect of the assemblage is seen in the presence of a transitional form intermediate between $S$. bigoti and $S$. laffittei Noël. Studies of Jurassic coccolith assemblages in Europe indicate that $S$. bigoti disappeared and $S$. laffittei appeared during the late Jurassic (Noël 1965; Stradner 1963).

Age-diagnostic Coccoliths in Selected Samples, Holes 5 and $5 \mathrm{~A}$

\section{Pleistocene}

Sample a $\quad(1-5-1-1,1 \mathrm{~cm}$, depth $0 \mathrm{~m})$ : Ceratolithus cristatus Kamptner; Cyclococcolithus leptoporus (Murray and Blackman); Gephyrocapsa oceanica Kamptner; Helicopontosphaera kamptneri Hay and Mohler; Rhabdosphaera clavigera (Murray and Blackman).

\section{Early Miocene}

Sample b $\quad(1-5-1-2,139-142 \mathrm{~cm}$, depth $3 \mathrm{~m})$ : Coccolithus sp. aff. $C$. bisectus Hay, Mohler, and Wade; Cyclococcolithus neogammation Bramlette and Wilcoxon; Discoaster deflandrei Bramlette and Riedel; Helicopontosphaera intermedia (Martini); H. kamptneri Hay and Mohler;H. truncata (Bramlette and Wilcoxon); Sphenolithus sp. aff. $S$. belemnos Bramlette and Wilcoxon.

\section{Pliocene with Chaotic Mixing}

Sample c $\quad(1-5-1-3,74 \mathrm{~cm}$, depth $4 \mathrm{~m})$ :

Ceratolithus rugosus Bukry and Bramlette; Discoaster pentaradiatus Tan; $D$. surculus Martini and Bramlette. Reworked taxa: Arkhangelskiella parca Stradner; Braarudosphaera discula Bramlette and Riedel; $B$. rosa Levin and Joerger; Cruciplacolithus sp.; Cyclococcolithus neogammation Bramlette and Wilcoxon; Discoaster barbadiensis Tan; D. brouweri rutellus Gartner; D. multiradiatus Bramlette and Sullivan; Nannoconus steinmanni Kamptner; Peritrachelina joidesa Bukry and Bramlette; Sphenolithus belemnos Bramlette and Wilcoxon; Stephanolithion laffittei Noël; Watznaueria barnesae (Black).

\section{Early Oligocene}

Sample d (1-5-1, core catcher, depth $4 \mathrm{~m})$ : Braarudosphaera rosa Levin and Joerger; Peritrachelina joidesa Bukry and Bramlette; Coccolithus bisectus Hay, 
Mohler, and Wade; Cyclococcolithus neogammation Bramlette and Wilcoxon; Discoaster tani tani Bramlette and Riedel; Helicopontosphaera compacta (Bramlette and Wilcoxon); Sphenolithus predistentus Bramlette and Wilcoxon. Reworked taxon: Marthasterites tribrachiatus Bramlette and Riedel.

\section{Late Cretaceous (Coniacian to Early Santonian)}

Sample e (1-5-2-1, 89-90 cm, depth $32 \mathrm{~m})$ :

Cribrosphaera ehrenbergi Arkhangelsky; Eiffellithus turriseiffeli (Deflandre); Lithastrinus floralis Stradner; Micula decussata Vekshina; Prediscosphaera cretacea (Arkhangelsky); Watznaueria actinosa (Stover); W. barnesae (Black).

Sample f $\quad(1-5-3-1,4-7 \mathrm{~cm}$, depth $71 \mathrm{~m})$ :

Lithastrinus floralis Stradner; Marthasterites furcatus Deflandre; Micula decussata Vekshina; Watznaueria actinosa (Stover).

\section{Age Unknown}

Sample g (1-5A-1, depth $85 \mathrm{~m})$ :

Barren.

\section{Late Cretaceous (Early Cenomanian)}

Sample h (1-5A-2, core catcher, depth $98 \mathrm{~m})$ : Lithastrinus floralis Stradner; Prediscosphaera cretacea (Arkhangelsky); Watznaueria barnesae (Black); Zygodiscus ponticulus (Deflandre); Z. xenotus (Stover).

\section{Early Cretaceous (Late Albian)}

Sample i (1-5A-3, core catcher, depth $145 \mathrm{~m})$ : Apertapetra gronosa (Stover); Arkhangelskiella striata Stradner; Corollithion delftensis (Stradner, Adamiker, and Maresch); C. signum Stradner; Cretarhabdus decorus (Deflandre); Parhabdolithus angustus (Stradner); P. embergi Noël; Prediscosphaera columnatus (Stover); Zygodiscus erectus (Deflandre); Z. ponticulus (Deflandre).

\section{Early Cretaceous (Hauterivian)}

Sample j (1-5A-4-1, $24 \mathrm{~cm}$, depth $185 \mathrm{~m})$ : Braarudosphaera discula Bramlette and Riedel of Stradner; Cruciplacolithus sp.; Discolithus rugosus Noël; Lithraphidites carniolensis Deflandre; Micrantholithus obtusus Stradner; Nannoconus globulus Brönnimann; Parhabdolithus embergi (Noël); Stephanolithion laffittei Noël; Watznaueria barnesae (Black).

\section{Early Cretaceous (Valanginian)}

Sample k (1-5A-6, core catcher, depth $236 \mathrm{~m}$ ):

Braarudosphaera discula Bramlette and Riedel of Stradner; Cruciplacolithus sp.; Cyclagelosphaera margereli Noel; Discolithus asper Stradner; Lithraphidites carniolensis Deflandre; Nannoconus bermudezi Bronnimann; $N$. globulus Bronnimann; N. steinmanni Kamptner; Parhabdalithus embergi Noel; Rhabdosphaera sp.;
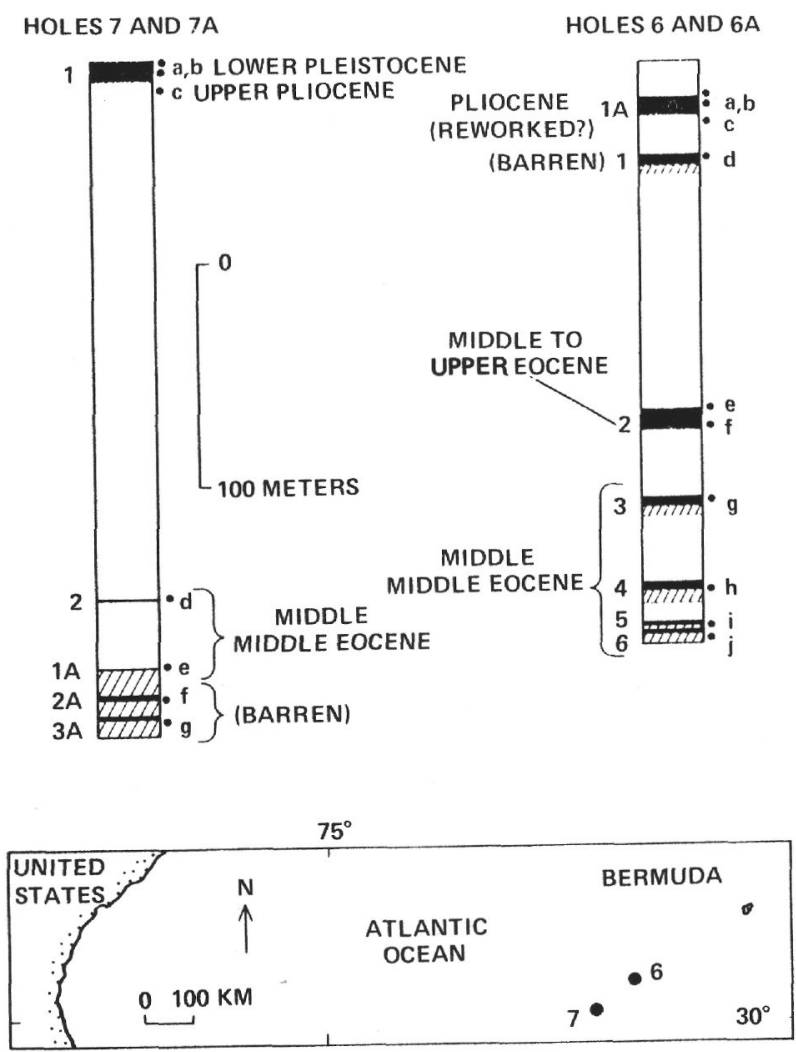

Figure 3. Series represented in cores from the Bermuda Rise based on coccolith assemblages. Core number to left of columns, sample to right.

Stephanolithion laffittei Noël; Watznaueria barnesae (Black).

Late Jurassic (Tithonian)

Sample 1 (1-5A-7, core catcher, depth $274 \mathrm{~m}$ ): Braarudosphaera discula Bramlette and Riedel of Stradner; Cruciplacolithus sp.; Cyclagelosphaera margereli Noël; Diazomatolithus lehmani Noël; Discolithus rugosus Noël; Nannoconus dolomiticus Cita and Pasquaré; N. steinmanni Kamptner; Parhabdolithus embergi Noël; $P$. sp. cf. P. marthe Noël; Rhabdosphaera sp.; Stephanolithion bigoti Noël; $S$. laffittei Noël; Watznaueria barnesae (Black); W. britannica (Stradner).

\section{HOLES 6 AND 6A}

(lat $30^{\circ} 50.4^{\prime} \mathrm{N}$., long $67^{\circ} 38.9^{\prime} \mathrm{W}$., depth 5125 meters)

\section{Summary of Coccolith Age Determinations}

Cores recovered from Holes 6 and 6A contain coccolith assemblages ranging in age from early Tertiary to late Tertiary or Quaternary. The upper two cores are virtually barren of calcareous microfossils, however, in one interval (1-6A-1A-1, 64-75 cm) coccoliths and discoasters are present. The species present indicate an 
assemblage of Pliocene age. Occurrence of this assemblage within a sequence of deep marine red clay, that is otherwise barren, suggests that the assemblage may have been redeposited from older and shallower beds. Diatoms present in 1-6-2, top of recovery, are distinctive of Middle or Upper Eocene assemblages throughout the world. For instance, the assemblages from Hole 6 are similar to those present at Mt. Diablo, California (Kanaya, 1957), in the Scripps Institution of Oceanography Middle Eocene DWBG \#23B core-catcher sample from the Pacific Ocean (16-42S. and 145-48W.), and in the Upper Eocene Oamaru Diatomite of New Zealand. No calcareous microfossils are present. The remaining samples in this hole contain rich microfossil assemblages of both coccoliths and diatoms. The coccolith species indicate that the assemblages are middle Middle Eocene in age in all cases. The best correlation to the biostratigraphic reference sections in Trinidad is to the coccolith assemblage of the Globigerapsis kugleri Range Zone of Bolli (1966). There appears to be little difference in the age of the coccolith assemblages recovered between the subbottom depths of 191 meters and 267 meters.

In examining outcrop and deep-sea piston core samples, M. N. Bramlette notes that Middle and Upper Eocene samples commonly contain abundant siliceous microfossils, such as diatoms and radiolarians, in association with volcanic ash beds. In addition to promoting growth of diatoms and radiolarians, the ash concentrations probably contribute to the sediment chemistry state that favors preservation of siliceous microfossils. Recoveries from this site on the Bermuda Rise attest further to the great bloom and preservation of microplankton-bearing siliceous skeletons from the Eocene oceans.

Age-diagnostic Coccoliths in Selected Samples, Holes 6 and 6A

Pliocene or Reworked Pliocene

Sample a (1-6A-1-1, $1 \mathrm{~cm}$, depth $15 \mathrm{~m})$ :

Barren.

Sample b (1-6A-1-1, 64-75 cm, depth $16 \mathrm{~m})$ :

Coccolithus doronicoides Black and Barnes; Cyclococcolithus leptoporus (Murray and Blackman), var. A of McIntyre, Bé, and Preikstas; Discoaster brouweri Tan; D. surculus Martini and Bramlette; Helicopontosphaera kamptneri Hay and Mohler.

Sample c (1-6A-1A, core catcher, depth $24 \mathrm{~m})$ : Barren.

Age Unknown

Sample d (1-6-1, depth $41 \mathrm{~m}$ to $46 \mathrm{~m})$ :

Barren.
Middle or Upper Eocene (dating based on diatoms only)

Sample e (1-6-2, top of recovery, depth $152 \mathrm{~m}$ ):

Hemiaulus polycystinorum Ehrenberg, var. Mesolepta Grunow; H. polymorphus Grunow; Pyxilla (Pterotheca) aculeifera (Grunow ex Van Heurck); ?P. (Pyxilla) intermedia Tempère and Forti; Stephanopyxis turris (Greville and Arnott) Ralfs, var. intermedia Grunow; Triceratium barbadense Greville.

Sample f (1-6-2, core catcher, depth $161 \mathrm{~m})$ :

Barren.

\section{Middle Middle Eocene}

Sample g (1-6-3-2, 49-52 cm, depth $193 \mathrm{~m})$ : Chiasmolithus expansus (Bramlette and Sullivan); $C$. grandis (Bramlette and Riedel); Chiphragmalithus quadratus Bramlette and Sullivan; Cyclococcolithus luminis Sullivan; C. lusitanicus (Black); Discoaster barbadiensis Tan; $D$. saipanensis Bramlette and Riedel; Reticulofenestra umbilica (Levin).

Sample h (1-6-4, core catcher, depth $234 \mathrm{~m})$ : Chiasmolithus grandis (Bramlette and Riedel); Cyclococcolithus gammation Bramlette and Sullivan; C. luminis Sullivan; C. lusitanicus (Black); Discoaster barbadiensis Tan; D. saipanensis Bramlette and Riedel; Reticulofenestra umbilica (Levin); Sphenolithus furcatolithoides Locker.

Sample i (1-6-5, core catcher, depth $249 \mathrm{~m})$ : Chiasmolithus expansus (Bramlette and Sullivan); $C$. grandis (Bramlette and Riedel); Cyclococcolithus gammation Bramlette and Sullivan; C. lusitanicus (Black); Discoaster barbadiensis Tan; D. saipanensis Bramlette and Riedel; Helicopontosphaera seminulum seminulum (Bramlette and Sullivan); Lanternithus minutus Stradner; Reticulofenestra umbilica (Levin).

Sample j (1-6-6-1, 146-149 cm, depth $251 \mathrm{~m})$ : Chiasmolithus expansus (Bramlette and Sullivan); $C$. gigas (Bramlette and Sullivan); C. grandis (Bramlette and Riedel); C. solitus (Bramlette and Sullivan); $C$. staurion (Bramlette and Sullivan); Discoaster barbadiensis Tan; D. saipanensis Bramlette and Riedel; Lophodolithus sp. aff. L. mochlophorus Deflandre; Reticulofenestra sp. aff. $R$. umbilica (Levin); Sphenolithus furcatolithoides Locker. Reworked taxa: Discoaster sublodoensis Bramlette and Sullivan; Micula decussata Vekshina; Rhabdosphaera inflata Bramlette and Sullivan.

\section{HOLES 7 AND 7A}

(lat $30^{\circ} 08.0^{\prime} \mathrm{N}$., long $68^{\circ} 17.8^{\prime} \mathrm{W}$., depth 5185 meters)

\section{Summary of Coccolith Age Determinations}

A 9.1-meter surface core, from 0.0 to 9.1 meters below the ocean floor, recovered a sequence of coccolith assemblages indicating that the boundary between the 
Tertiary and Quaternary is present near the top of this recovery. Coccoliths indicating an early Quaternary age are present at the top of the core. There are no Gephyrocapsa oceanica Kamptner recorded in the upper 90 centimeters of the core, and only rare reworked specimens of Discoaster brouweri Tan are present. A sample at 95 centimeters below the top of the core contains abundant specimens of $D$. brouweri. There are approximately equal proportions of six-rayed and three-rayed varieties. The relative abundance of the three-rayed specimens indicates a late Pliocene age. Coccoliths and discoasters become less abundant lower in the core; however, in a sample 208 centimeters below the surface, both $D$. brouweri and $D$. pentaradiatus Tan are present. These were the two dominant discoasters of Pliocene time, and they-the last of the discoasters-became extinct at about the time generally assigned to the Pliocene-Quaternary boundary. Coccoliths are quite rare in a sample at 276 centimeters below the surface, and the remaining samples consist of barren deep-sea clay.

Core 2 recovered middle Middle Eocene coccolith- and diatom-rich sediment and correlates with similar cores described from Hole 6.

In redrilling Site 7 , the first coring was not attempted until after 267 meters of subbottom penetration. The core barrel was apparently empty when it was retrieved, but when the core-catcher assembly, which was unused before this coring, was dismantled, three specks of sediment totalling less than 1 cubic millimeter were recovered. Three smear slides were made to examine the contained coccoliths. All three coccolith assemblages proved to be middle Middle Eocene. On the basis of this information, the decision was made to continue drilling instead of attempting another core at this level. The next two core recoveries, the last of this leg, retrieved deep-sea silty clay that contained neither coccoliths nor diatoms, and its age is unknown.
Age-diagnostic Coccoliths in Selected Samples, Holes 7 and $7 \mathrm{~A}$

\author{
Early Pleistocene
}

Sample a (1-7-1-1, $80 \mathrm{~cm}$, depth $1 \mathrm{~m})$ :

Ceratolithus rugosus Bukry and Bramlette; Coccolithus doronicoides Black and Barnes; Cyclococcolithus leptoporus Murray and Blackman.

\section{Late Pliocene}

Sample b (1-7-1-1,95 cm, depth $1 \mathrm{~m})$ : Ceratolithus rugosus Bukry and Bramlette; Coccolithus doronicoides Black and Barnes; Cyclococcolithus leptoporus Murray and Blackman; Discoaster brouweri Tan.

Sample c (1-7-1, core catcher, depth $9 \mathrm{~m})$ :

Barren.

\section{Middle Middle Eocene}

Sample d (1-7-2, core catcher, depth $236 \mathrm{~m})$ : Chiasmolithus expansus (Bramlette and Sullivan); $C$. gigas (Bramlette and Sullivan); C. grandis (Bramlette and Riedel); Chiphragmalithus cristatus (Martini); Discoaster elegans Bramlette and Sullivan; Helicopontosphaera seminulum lophota (Bramlette and Sullivan); Reticulofenestra umbilica (Levin).

Sample e (1-7A-1, core catcher, depth $267 \mathrm{~m})$ : Chiasmolithus solitus (Bramlette and Sullivan); Cyclococcolithus gammation Bramlette and Sullivan; C. lusitanicus (Black); Discoaster barbadiensis Tan; Reticulofenestra sp. aff. R. umbilica (Levin); Rhabdosphaera spinula Levin.

\section{Age Unknown}

Sample f (1-7A-2, composite, depth $278 \mathrm{~m}$ to $290 \mathrm{~m})$ : Barren.

Sample g (1-7A-3, composite, depth $287 \mathrm{~m}$ to $290 \mathrm{~m}$ ): Barren. 


\section{PLATE 1}

Coccolith replica electronmicrographs (magnifications: 10,000 $\mathrm{X}$, unless stated).

Hole 5A, Core 3A, core catcher (145 meters subbottom)

A Apertapetra gronosa (Stover) magnification: $5,000 \mathrm{X}$

B Arkhangelskiella erratica Stover

C Costacentrum horticum (Stradner, Adamiker, and Maresch)

D Cretarhabdus crenulatus Bramlette and Martini

E Cretarhabdus decorus (Deflandre) magnification: $9,000 \mathrm{X}$

F Cretarhabdus decussatus (Manivit)

\section{PLATE 2}

Coccolith replica electronmicrographs (magnifications: $10,000 \times$, unless stated).

Hole 5A, Core 3A, core catcher (145 meters subbottom)

A Eiffellithus turriseiffeli (Deflandre) magnification: $8,000 \mathrm{X}$

B-C Parhabdolithus sp.

D Podorhabdus dietzmanni (Reinhardt)

E Prediscosphaera columnatus (Stover)

F Scapholithus fossilis Deflandre

\section{PLATE 3}

Coccolith replica electronmicrographs

Hole 5A, Core 7A, core catcher (274 meters subbottom)

A Bidiscus sp.

magnification: $14,000 \times$

B Cretarhabdus sp. cf. C. crenulatus Bramlette \& Martini

C-D ?Cruciplacolithus sp. magnifications: $7,000 \mathrm{X}$

E Diazomatolithus lehmani Noël magnification: $10,000 \mathrm{X}$

F Parhabdolithus embergi Noël magnification: $7,000 \times$

\section{PLATE 4}

Coccolith replica electronmicrographs

Hole $5 A$, Core $7 A$, core catcher (274 meters subbottom)

A Rucinolithus sp. aff. R. hayi Stover magnification: $10,000 \times$

B Stephanolithion sp. magnification: $14,000 \mathrm{X}$
C Watznaueria barnesae (Black)

magnification: $10,000 X$

D-E Watznaueria britannica (Stradner) magnifications: $7,000 \mathrm{X}$

F Zygodiscus sp. $\operatorname{cff} Z$ theta (Black)

magnification: $7,000 X$

PLATE 5

Coccolith replica electronmicrographs (magnifications: 10,000 $\mathrm{X}$, unless stated). Hole 5A, Core 4A, Section 1, $24 \mathrm{~cm}$ (185 meters subbottom)

A Biscutum blacki Gartner magnification: $15,000 \mathrm{X}$

B Corollithion sp.

C ?Cruciplacolithus sp. magnification: $6,000 \mathrm{X}$

D Micrantholithus obtusus Stradner

E Stephanolithion laffittei Noël

F Zygodiscus erectus (Deflandre)

\section{PLATE 6}

Coccolith replica electronmicrographs (magnifications: 10,000 $\mathrm{X}$, unless stated). Hole 3, Core 9, Section 3, $75 \mathrm{~cm}$ (537 meters subbottom)

A-B Discoaster sp.

A magnification: $9,000 \times$

B magnification: $6,000 \times$

C Discoaster sp. aff. D. brouweri Tan

D Discolithina sp. magnification: $6,000 \mathrm{X}$

E Helicopontosphaera kamptneri Hay and Mohler

F Sphenolithus abies Deflandre magnification: $16,000 \times$

\section{PLATE 7}

Coccolith replica electronmicrographs (magnifications: 5,000 $\times$, unless stated). Hole 3, Core 8, Section 6, $72 \mathrm{~cm}$ (438 meters subbottom)

A Ceratolithus tricorniculatus Gartner magnification: $8,000 \times$

B Scyphosphaera pulcherrima Deflandre

C Discoaster brouweri Tan

D Discoaster surculus Martini and Bramlette

E-F Reticulofenestra pseudoumbilica (Gartner) magnification: $10,000 \mathrm{X}$ 
PLATE 1.
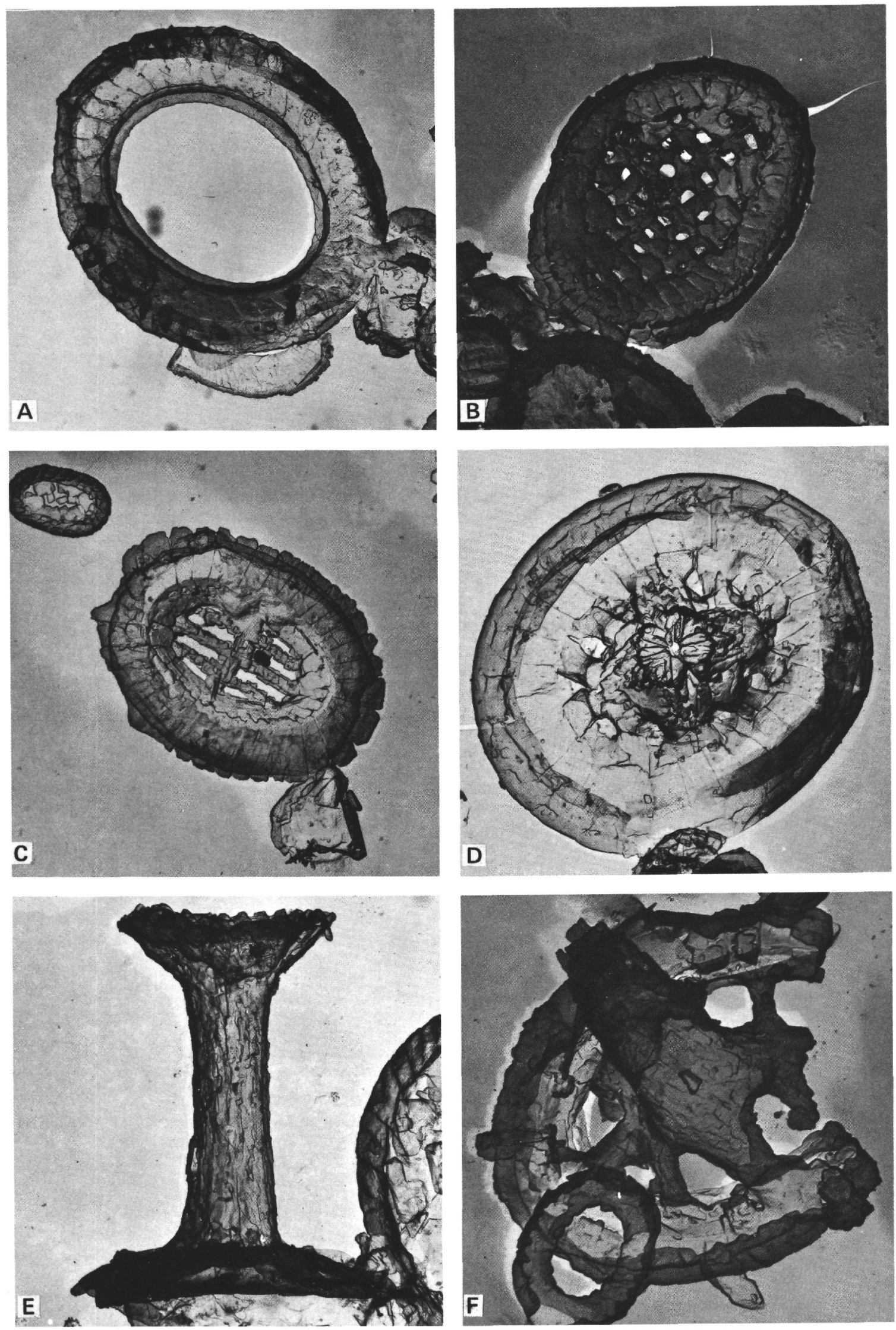
PLATE 2.
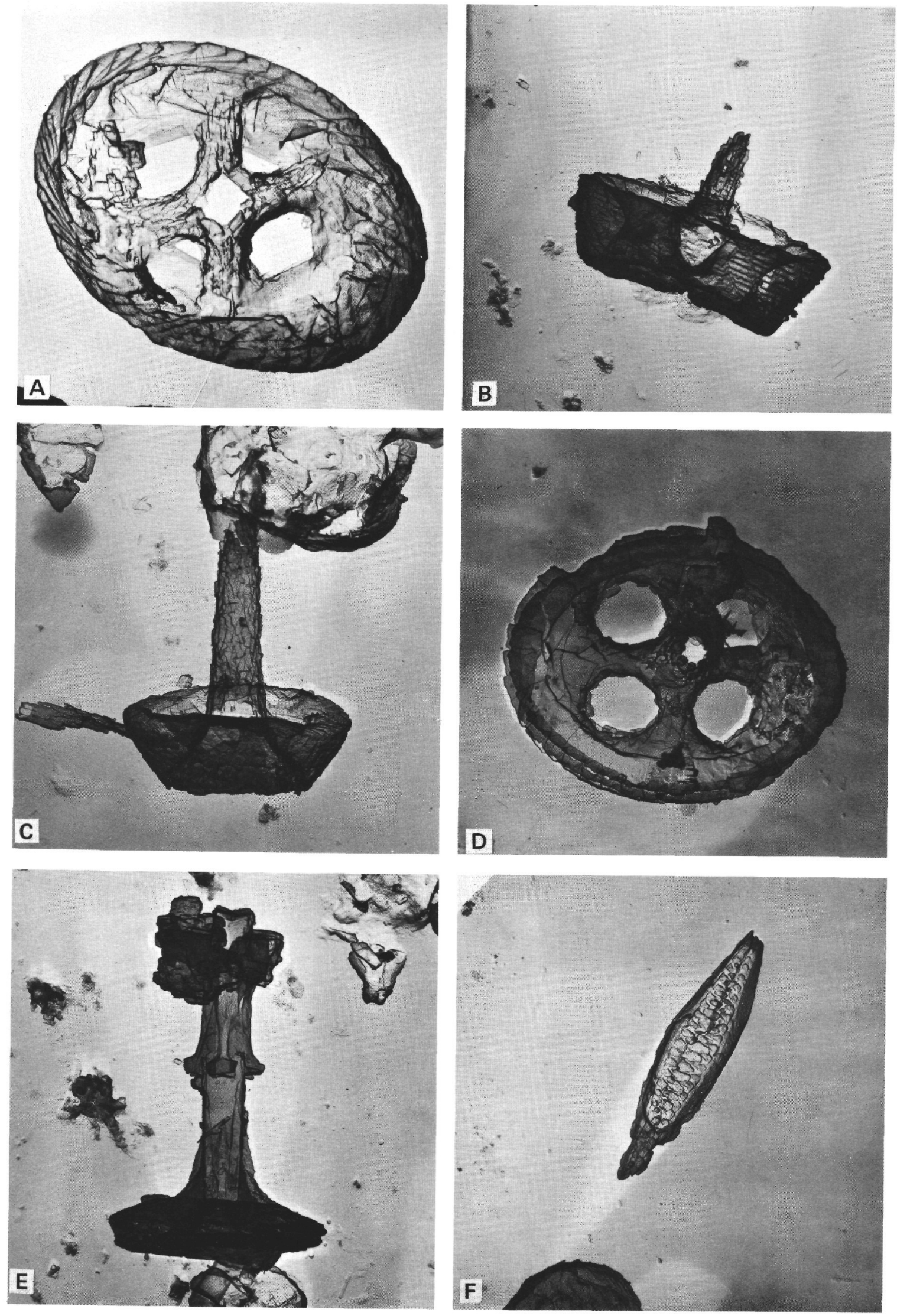
PLATE 3.
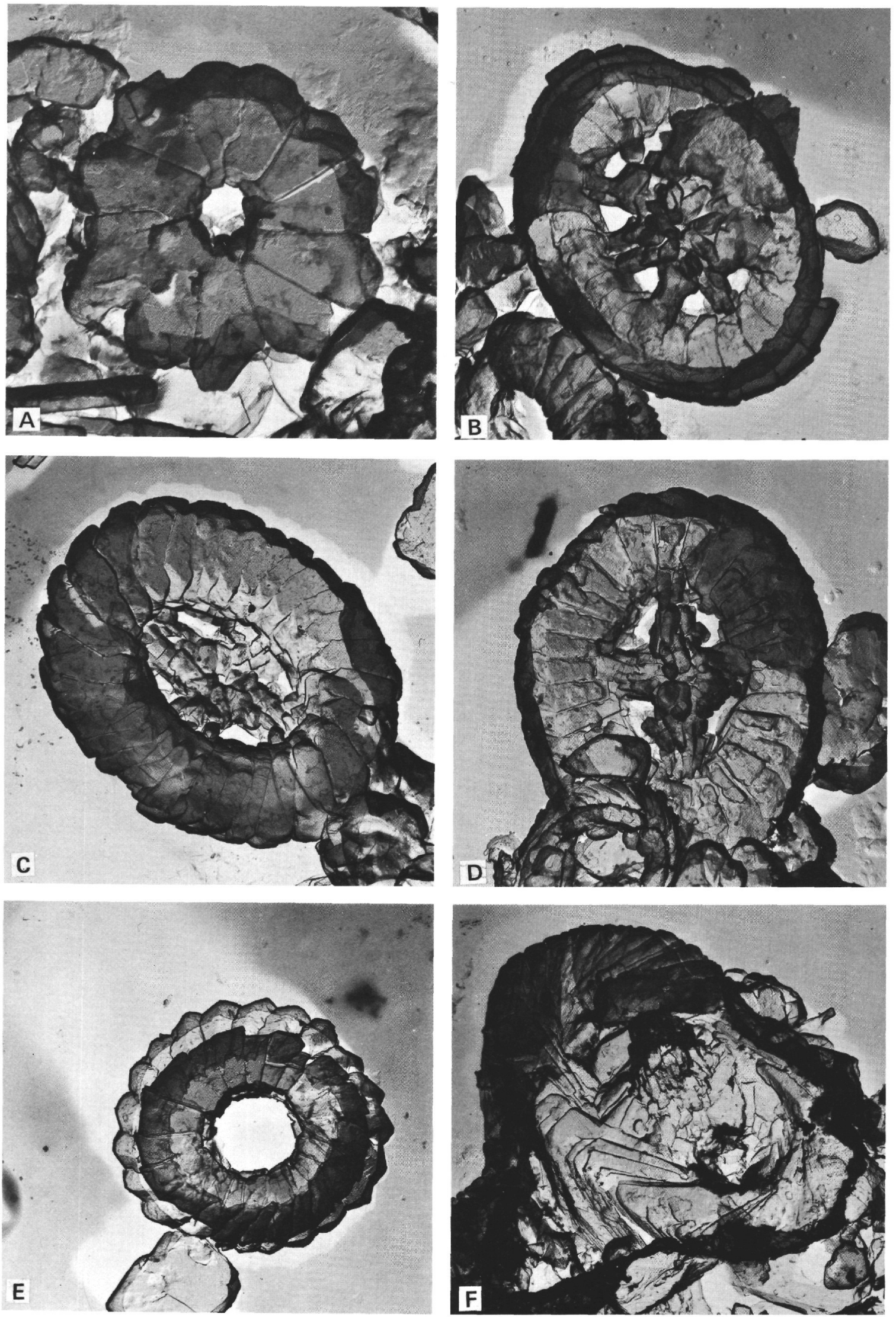
PLATE 4.
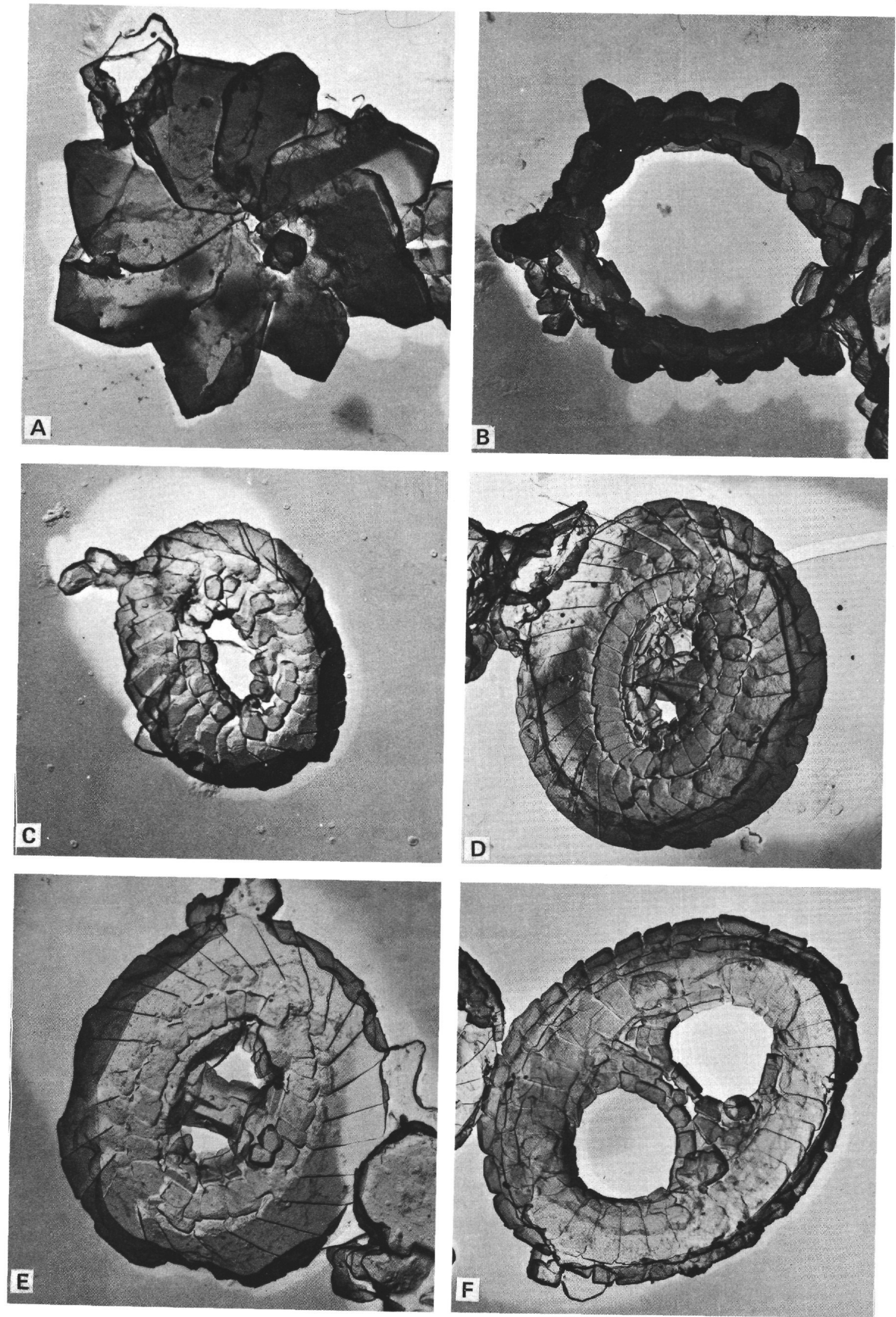
PLATE 5.
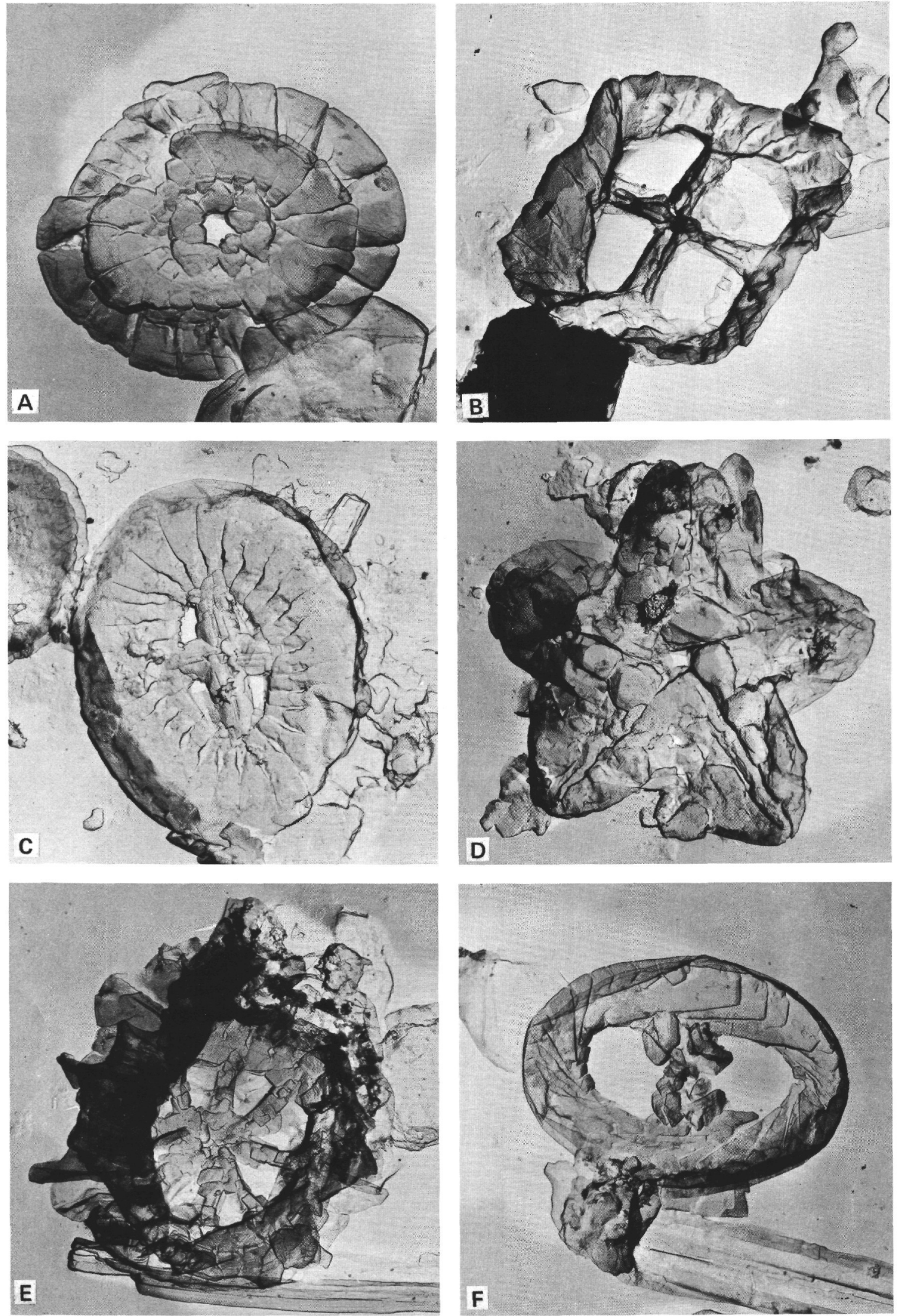
PLATE 6.
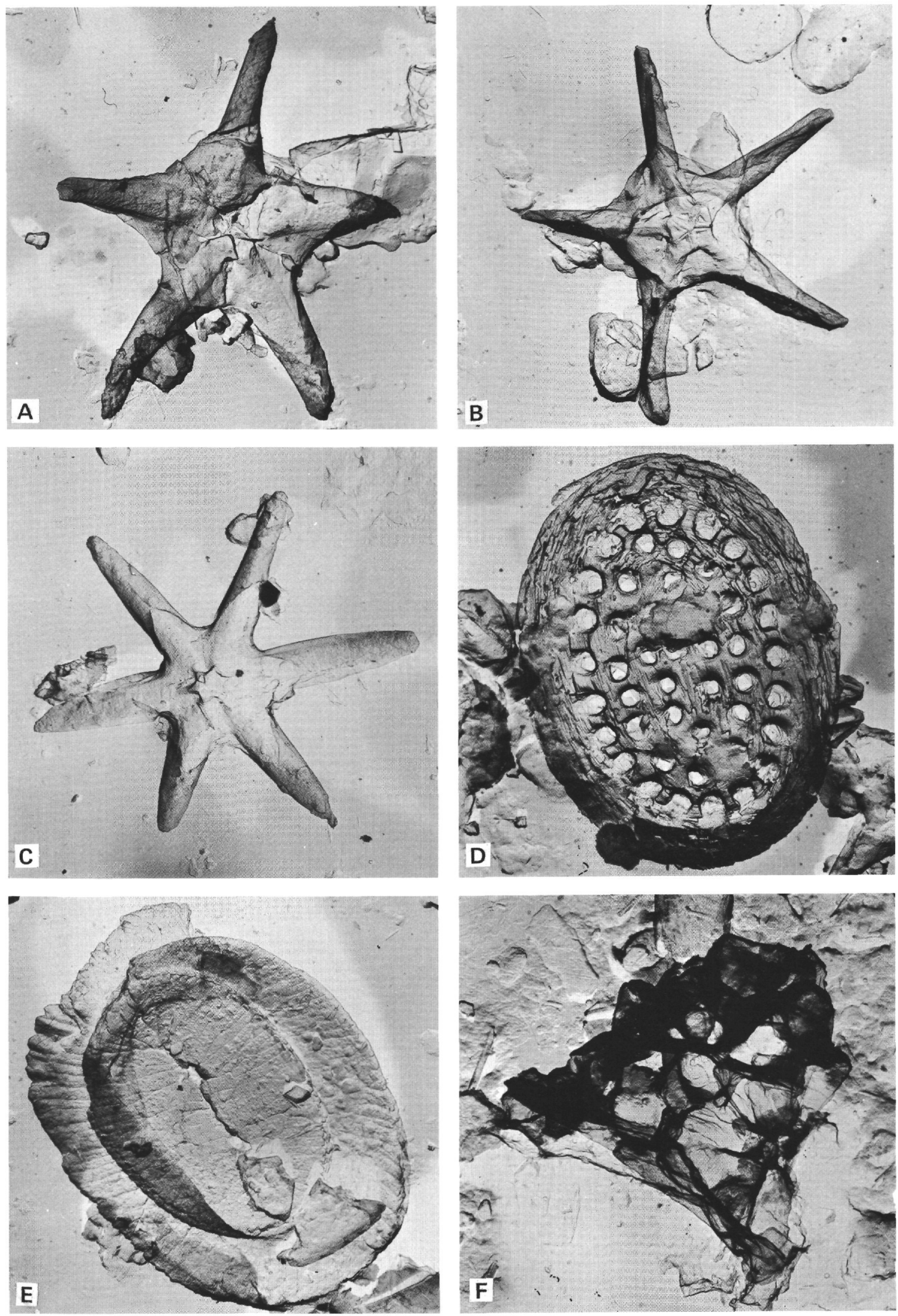
PLATE 7.
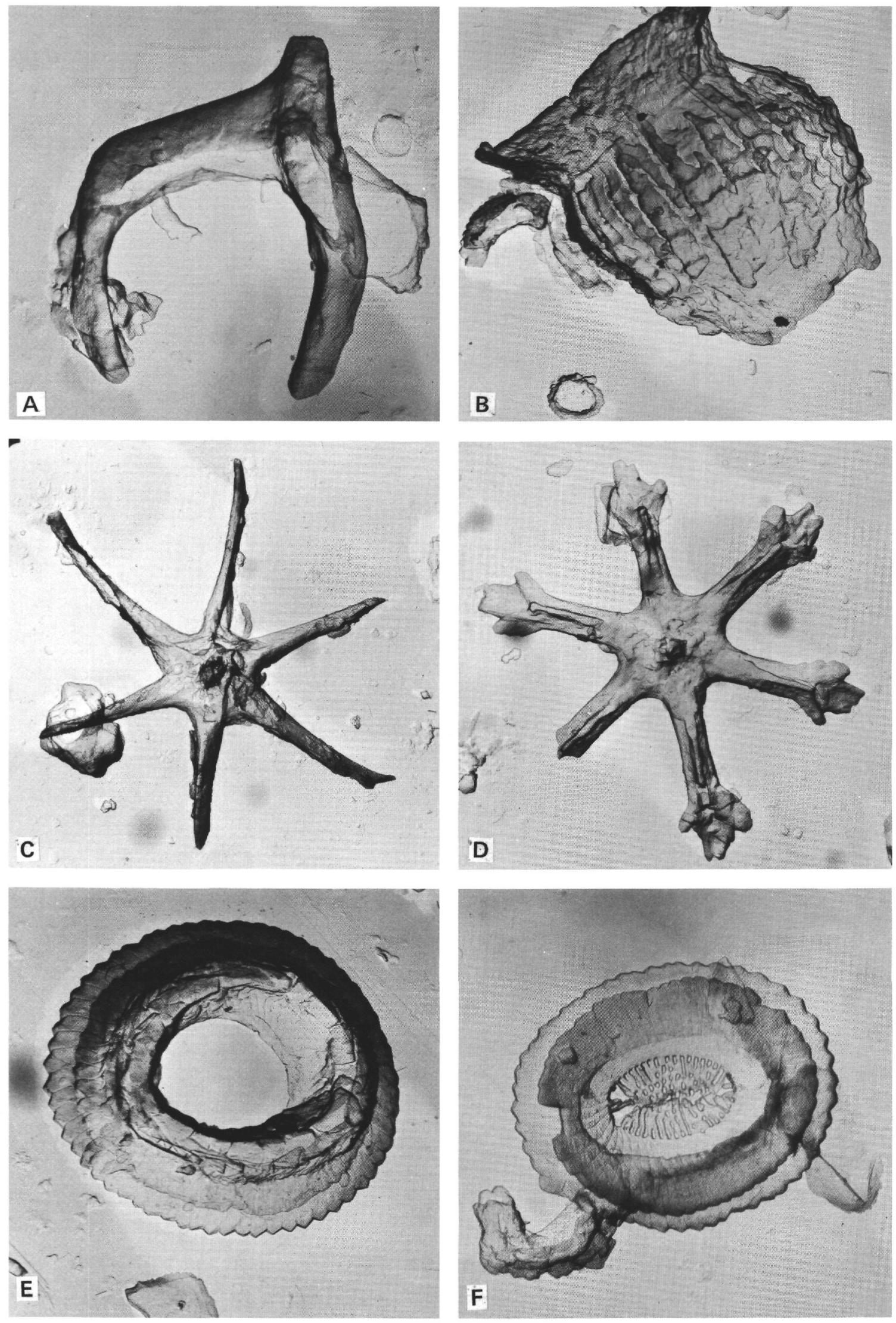


\section{REFERENCES}

Arkhangelsky, A. D., 1912. Verkhnemelovyya otlozheniya vostoka evropeiskoi Rossii (Upper Cretaceous deposits of east European Russia). Material Geol. Russland. 25, 631 .

Black, M., 1964. Cretaceous and Tertiary coccoliths from Atlantic seamounts. Palaeontology. 7, 306.

Black, M. and Barnes, B., 1961. Coccoliths and discoasters from the floor of the South Atlantic Ocean. Roy. Microscop. Soc. J. 80, 137.

Bolli, H. M., 1966. Zonation of Cretaceous to Pliocene marine sediments based on planktonic foraminifera. Bol. Assoc. Venezolana Geol. Mineria Petrol. 9 (1), 3 .

Bouché, P. M., 1962. Nannofossiles calcaires du Lutétien du bassin de Paris. Rev. Micropaléontologie. 5 (2), 75.

1965. État des connaissances sur les nannofossiles calcaires du Crétacé inférieur. Bur. Recherches Géol. Minières Mém. 34, 451.

Bramlette, M. N. and Martini, E., 1964. The great change in calcareous nannoplankton fossils between the Maestrichtian and Danian. Micropaleontology. 10 (3), 291.

Bramlette, M. N. and Riedel, W. R., 1954. Stratigraphic value of discoasters and some other microfossils related to Recent coccolithophores. J. Paleontology. 28 (4), 385.

Bramlette, M. N. and Sullivan, F. R., 1961. Coccolithophorids and related nannoplankton of the early Tertiary in California. Micropaleontology. 7 (4), 129.

Bramlette, M. N. and Wilcoxon, J. A., 1967. Middle Tertiary calcareous nannoplankton of the Cipero section, Trinidad, W. I. Tulane Studies Geology, $5,93$.

Brönnimann, P., 1955. Microfossils incertae sedis from the Upper Jurassic and Lower Cretaceous of Cuba. Micropaleontology. 1 (1), 28.

Bukry, D., 1969. Upper Cretaceous coccoliths from Texas and Europe. Univ. Kansas Publ. State Geol. Surv. Kansas Bull. Paleont. Contr., Protista, art. 2, 79.

Bukry, D. and Bramlette, M. N., 1968. Stratigraphic significance of two genera of Tertiary calcareous nannofossils. Tulane Studies Geology. 6, 149.

Deflandre, G., 1952. Classe des Coccolithophoridés. In Traité de paléontologie. Piveteau, J. (Ed.), Paris, (Masson et Cie), 1, 99.

1959. Sur les nannofossiles calcaires et leur systématique. Rev. Micropaléontologie. 2 (3), 127.

Deflandre, G. and Fert, C., 1954. Observations sur les coccolithophoridés actuels et fossiles en microscopie ordinaire et électronique. Ann. Paléontologie. 40, 115 .

Gartner, S., Jr., 1967. Calcareous nannofossils from Neogene of Trinidad, Jamaica, and Gulf of Mexico.
Univ. Kans. Publ. State Geol. Surv. Kansas Bull. Paleont. Contr., Paper 29, p. 1.

1968. Coccoliths and related calcareous nannofossils from Upper Cretaceous deposits of Texas and Arkansas. Univ. Kansas Publ. State Geol. Surv. Kansas Bull. Paleont. Contr. 48, art. 1, 56.

Hay, W. W., Mohler, H., Roth, P. H., Schmidt, R. R. and Boudreaux, J. E., 1967. Calcareous nannoplankton zonation of the Cenozoic of the Gulf Coast and Caribbean-Antillean area, and transoceanic correlation, In Symposium on the geological history of the Gulf of Mexico, Antillean-Caribbean region. Trans. Gulf Coast Assoc. Geol. Soc. 17, 428.

Hay, W. W., Mohler, H. and Wade, M. E., 1966. Calcareous nannofossils from Nal'chik (Northwest Caucasus). Eclogae Geol. Helvetiae. 59 (1), 379.

Kamptner, E., 1954. Untersuchungen über den Feinbau der Coccolithen. Archiv. Protistenkunde. 100 (1), 90.

Kanaya, T., 1957. Eocene diatom assemblages from the Kellogg and "Sidney" Shales, Mt. Diablo area, California. Sci. Rept. Tohoku Univ. Second Sr. 28, 27.

Levin, H. L., 1965. Coccolithoporidae and related microfossils from the Yazoo formation (Eocene) of Mississippi. J. Paleontology. 39, 265.

Levin, H. L. and Joerger, A. P., 1967. Calcareous nannoplankton from the Tertiary of Alabama. Micropaleontology. 13 (2), 163.

Locker, S., 1967. Neue Coccolithophoriden (Flagellata) aus dem Alttertiar Norddeutschlands. Geologie. 16, 361 .

Martini, E. and Bramlette, M. N., 1963. Calcareous nannoplankton from the experimental Mohole drilling. Paleontology. 37 (4), 845.

McIntyre, A., Bé, A. W. H. and Preikstas, R., 1967. Coccoliths and the Pliocene-Pleistocene boundary. In Progress in oceanography -V. 4, The Quaternary history of the ocean basins. London and New York (Pergamon Press), 3.

Murray, G. and Blackman, V. H., 1898. On the nature of the coccospheres and rhabdospheres. Phil. Trans. Roy. Soc. London. 190B, 427.

Noël, D., 1956. Coccolithes des terrains jurassiques de l'Algerie. Algéria, Serv. Carte Géol. new ser. Bull. 8, 303.

1958. Etude de coccolithes du jurassique et du crétace inférieur. Algeria, Serv. Carte Géol. new ser., Bull. 20, 155.

1965. Sur les Coccolithes du Jurassique Europeen et d'Afrique du Nord. Paris, Centre Natl. Recherche Sci. 209.

Reinhardt, P., 1964. Einige Kalkflagellaten-Gattungen (Coccolithophoriden, Coccolithineen) aus dem Mesozoikum Deutschlands. Deutsche Akad. Wiss. Berlin Monatsber. 6, 749 . 
1966. Zur Taxionomie und Biostratigraphie des fossilen Nannoplanktons aus dem Malm, der Kreide und dem Alttertiär Mittleuropas. Freiberger Forsch. No. C196, 5.

Stover, L. E., 1966. Cretaceous coccoliths and associated nannofossils from France and the Netherlands. Micropaleontology. 12 (2), 133.

Stradner, H., 1964. New contributions to Mesozoic stratigraphy by means of nannofossils. World Petroleum Cong. 6th, Frankfurt am Main, Proc., sec. 1. 167.

Stradner, H. and Adamiker, D., 1966. Nannofossilien aus Bohrkernen und ihre elektronenmikroskopische Bearbeitung. Erdöl-Erdgas Zeitschr. 82, 330.
Stradner, H., Adamiker, D. and Maresch, O., 1968. Electron microscope studies on Albian calcareous nannoplankton from the Delft 2 and Leidschendam 1 deepwells, Holland. Koninkl. Ned. Akad. Wetenschap., Afd., Natuurk. Verh. sec. 1, 24 (4), 107.

Sullivan, F. R., 1965. Lower Tertiary nannoplankton from the California Coast Ranges-II, Eocene. Univ. California Pubs. Geol. Sci. 53, 1.

Tan, S. H., 1927. Discoasteridae incertae sedis. Koninkl. Ned. Akad. Wetenschap. Amsterdam Proc., Sec. Sci. 30 (3), 411.

Vekshina, V. N., 1959. Coccolithophoridan der Maastricht-Ablagerungen der westsibirischen Ebene (Coccolithophoridae of the Maastrichtian deposits of the west Siberian lowland). Siberia Nauch.-Issled. Inst. Geol. Geofiz. i Min. Syr'ya Trudy. 2, 56. 